\title{
Senior High School Teachers' Perceived Level of Communication Skills and Teaching Performance
}

\author{
Chelou M. Tizon ${ }^{1}$ \\ ${ }^{1}$ Department of Education, Philippines \\ Correspondence: Chelou M. Tizon, Department of Education, Philippines \\ Received: July 12, 2019; Accepted: August 7, 2019; Published: September 17, 2019
}

\begin{abstract}
Teachers handling subjects in English medium can help learners' develop English communicative competence if they themselves possess a high level of communication skills in the language. In this study, Division of Ozamiz City's senior high school teachers' perceived level of communication skills in English, teachers' teaching performance in developing learners' communicative competence, and the correlation between the two were explored. The quantitative research approach was utilized by collecting data from 75 senior high school teachers, ten school heads, and 356 learners using researcher-made instruments that passed the validity and reliability tests. Data were analysed through descriptive-correlational research design using mean and standard deviation and Pearson r- Pearson product-moment correlation. In this study, it is found out that teachers perceived themselves to be superior in terms of their English communication skills while school heads and learners perceived them to be outstanding in their teaching performance. Results also revealed that teachers' communication skills and teaching performance have no significant relationship. It is recommended that teachers be provided by school heads with opportunities to sustain their superior level of communication skills and outstanding teaching performance. More attention should be given to teachers' writing skills and being initiators of communicative situations as these two constructs received the lowest rating from the respondents.
\end{abstract}

Keywords: communicative situations, listening skills, reading skills, speaking skills, writing skills

\section{Introduction}

Education plays an indispensable role in the society and it is viewed as one of the prime engines for economic growth (Mishra, 2016). Educated individuals are considered great contributors to the development and progress in their respective countries (Camello, 2014). For these reasons, education is not only seen as a means of transmitting culture, knowledge, and values, but also as a contributor to economic development (Papp \& Hajós, 2014).

Aside from being a determinant of income situation (Stejskal \& Stávková, 2014), education is also considered an integral component for social prosperity and political stability (Kimonen, 2015). For a society to be progressive, educational framework is required (Anjum, 2017). And it is said that an education system that cannot make people socially, politically, and economically relevant is a system that fails to push for national development (Maduegbunam \& Okafor, 2014).

Modern society acknowledges the importance of education and this has led to the educational revamps in the past decades (Journal of Engineering, 2018). And as society expects schools to prepare students for their future career, demand for quality education has also increased (Savga, 2013). Education is seen to be important to all regardless of age and background (Emeck, 2018).

Now that the world is tagged as the 21 st-century world, more demands are placed upon education. One of which is for the schools to produce learners who possess the 21 st-century skills which include the communication skills (National Research Council, 2013). Different countries have taken moves to address this challenge of time by integrating communication skills in the core subjects of the curriculum (U.S. Newswire, 2017).

To many, developing communication skills is about developing one's skills in the English language (Majidi, 2013) for English is tagged as the lingua franca of the world (Naji \& Pishghadam, 2013). This language is used as the language for international mail and conferences and the tongue in commerce and aid (Smith, 2015). It is also linked with social and economic power. All these make a quality English language teaching-learning a huge concern around the world (Selvi \& Yazan, 2013).

A quality teaching-learning process requires quality teachers. Evidences of this claim have mounted along the years (Banchero, 2013). In the case of learning English, having a quality teacher is a key to having effective 
English language learning among students. For this reason, it is imperative for teachers to possess the qualities of being an effective communicator. This means that he must fluently use English with clear pronunciation, stress, and intonation (Braine, 2013). Moreover, he must be proficient in reading, writing, and comprehension (Badawood, 2015). As an effective learning facilitator, a teacher is also expected to have subject-specific knowledge and skills (Graham et al., 2014; Nghia, 2015). And since communication skill is the target of teaching English to students, teachers must also possess the macro skills in communication.

Communication skill is composed of four related macro skills - reading, writing, speaking, and listening (figure 1) which all undergo complex processes to achieve each of their goals. Reading decodes written symbols (Barrot, 2017). Listening is a combination of hearing what another person says, and considering the psychological involvement with the person who is talking (Tyagi, 2013). Writing is a process of reaching out for one's thought and discovering them; a process of meaning-making (Baliya et al., 2013). Speaking is making meaning and sharing this meaning through verbal and non-verbal symbols in a variety of contexts (Bahadorfar \& Omidvar, 2014).

The use of English language as medium of communication in the different subjects of the curriculum is aimed to making students competent in the four macro skills of the language (Ahmad, 2014). To achieve this target, it is important to also examine whether teachers who handle these subjects, also possess the four competences. This is to see teachers' needs so that they could be assisted in the field. If society considers education as valuable, it must equally value the importance of teachers and provide the needed support for them to carry out their task better (The Mercury, 2018).

The strong link between macro skills in communication and teaching performance encouraged the researcher to conduct this study to see the present level of communication skills and teaching performance of senior high school teachers in the Division of Ozamiz City. Furthermore, with the result of this study, this paper aimed to figure out the kind of assistance that may be given to the teachers to equip them with the skills and competences in communication, making them better facilitators in developing learners' communicative competence.

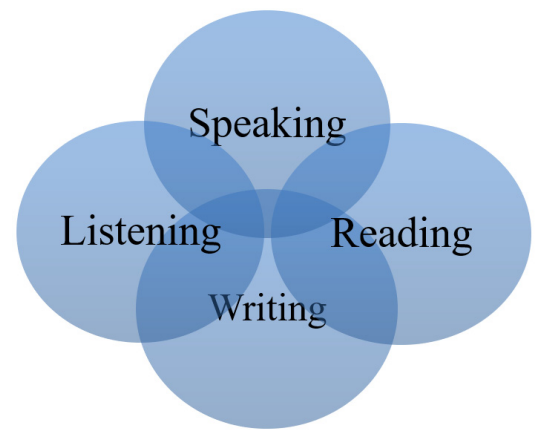

Figure 1. Macro skills in communication

\subsection{Objectives of the Study}

This study looked into the communication skills and teaching performance of the Senior High School teachers in the Division of Ozamiz City. The specific objectives were to:

1. Assess the teachers' level of communication skills in the English language as to reading, listening, writing, and speaking as perceived by the teachers;

2. Determine the teachers' teaching performance in the English language as to being proficient communicator and initiator of communicative situations as perceived by the school heads and the learners; and

3. Explore the significant relationship between teachers' level of communication skills and their teaching performance in the English language.

\section{Methods}

\subsection{Research Design}

This study used descriptive-correlational design. Descriptive design in research aims to accurately portray characteristics of individuals, situations or groups in a particular phenomenon. This design targets to find out the 'what' in a situation rather than the 'how' and the 'why.' Data in this design are treated using statistics. Correlational research, on the other hand, is a form of descriptive research since it describes an existing relationship between variables. In this design relationship among variables is identified, analyzed, interpreted, and tested (Ozdemir, 2013). In this study, the descriptive-correlational design was seen appropriate to use in assessing 
the level of communication skills among senior high school teachers, in evaluating their teaching performance, and in determining the correlation of the two variables.

\subsection{Research Setting}

This study was conducted in the Division of Ozamiz City, one of the fourteen divisions in Region X. This division is composed of 6 districts with 14 public secondary schools, 10 of which offers Senior High School.

Ozamiz, a city of Region X in Northern Mindanao, occupies an estimated land area of 16, 407 hectares. Originally, Ozamiz is an agricultural place but as modernization set into the city, it gradually converted into a center for commerce, health, transportation, and education among near places.

\subsection{Respondents of the Study}

The respondents of this study were the 75 senior high school teachers, ten school heads, and 356 senior high school learners. The 75 teachers who responded in this study were all regular senior high school teachers handling subjects in the English medium. These teachers were asked to rate their communication skills as to reading, listening, writing, and speaking.

The ten school heads, on the other hand, were composed of 7 school principals and 3 assistant principals for senior high school. Each of these principals and assistant principals serves as a school head in each of the ten public senior high schools in the division of Ozamiz City. These respondents had to rate the teaching performance of all the teacher-respondents of this study who are under their administration.

The 356 student-respondents of this study were chosen using stratified random sampling. They were composed of Grade 11 and Grade 12 students coming from the ten public senior high schools of Ozamiz City Division. These students were under the academic and technical-vocational and livelihood tracks. Each of them rated one teacher in terms of the latter's teaching performance. The number of students rating one particular teacher was determined through a statistically computed ratio.

\subsection{Research Instruments}

The following were the research instruments used in the gathering of data and information in the study:

A. Self - Assessment Survey for Communication Skills. This self-assessment survey, which aimed to measure teachers' communication skills in reading, listening, writing, and speaking as perceived by the teachers themselves, was adapted from the checklist produced by Carol J. Orwig, a certified Senior Language and Culture Learning Consultant, SIL International. The respondents of this tool were senior high school teachers. This tool was composed of 20 items with five items for each skill starting with reading and listening as receptive skills, then writing and speaking as productive skills. The interpretations of the level of communication skills range from novice, intermediate, advanced and superior.

Table 1. The continuum used in interpreting the gathered data

\begin{tabular}{lcl}
\hline \multicolumn{1}{c}{ Responses } & Continuum & Interpretation \\
\hline 4- Extremely Well (EW) & $3.25-4.0$ & Superior (S) \\
3 - Well (W) & $2.50-3.24$ & Advanced (A) \\
2- Somewhat (S) & $1.75-2.49$ & Intermediate (I) \\
1 - Not at all (NA) & $1.0-1.74$ & Novice (N) \\
\hline
\end{tabular}

B. Class Observation Tool for Teacher's Performance in Developing Learners' Communicative Competence. This tool which was adapted from one of the English teaching institutions in Vietnam, measured the teachers' performance being initiators and facilitators of communicative situations in class and as independent participants of the process. This tool had 13 indicators which were all subjected to validity and reliability test. The rating for each indicator was within the range of 1-4. The respondents of this tool were the school heads and the Senior High School students.

Table 2. The continuum used in interpreting the gathered data

\begin{tabular}{lll}
\hline Responses & Continuum & Interpretation \\
\hline 4- Always (A) & $3.25-4.0$ & Outstanding (O) \\
3- Sometimes (S) & $2.50-3.24$ & Very Satisfactory (VS) \\
\hline
\end{tabular}




\begin{tabular}{lll}
\hline $2-$ Seldom $(\mathrm{Sm})$ & $1.75-2.49$ & Satisfactory $(\mathrm{S})$ \\
$1-\operatorname{Never}(\mathrm{N})$ & $1.0-1.74$ & Fair $(\mathrm{F})$ \\
\hline
\end{tabular}

\subsection{Data Collection}

The researcher obtained approval to conduct the study from the Dean of the Graduate School of Misamis Univeristy. The researcher also asked permission from the Schools Division Superintendent, District Supervisors and Principals of the participating schools in Ozamiz City. Upon their approval, questionnaires were distributed to the teacher respondents and these were collected back on the set date. The researcher then performed the tallying and organizing of responses. Data analysis was done by the research statistician and interpretation of data was made by the researcher herself.

\subsection{Ethical Considerations}

To ensure confidentiality and anonymity of the respondents, the researcher made sure that the respondents have read and understood the important information about the research. The procedures regarding confidentiality were clearly explained such as use of names, pseudonyms, and anonymity of data. The school heads and the teachers signed consent while the students signed assent signifying their knowledge about the nature of the research and their voluntary participation to the study.

\subsection{Data Analysis}

The following were the statistical tools used in the study:

Mean and Standard Deviation. Mean and standard deviation are probably the most widely used statistics to describe distributed data (Zhang, 2016). For this study, mean was used to get a single value that would signify the level of communication skills and teaching performance of the teachers as perceived by the teachers themselves, the school heads and the learners. This value is the representation of the average of a 4-point rating scale with 20 items for communication skills and 13 items for teaching performance. The standard deviation, on the other hand, was used in this study to get the single number that tells the variability or spread of the distribution of scores.

Pearson Product-Moment Correlation. This tool measures the strength of a linear association between two variables and is denoted by $\mathrm{r}$. This was used to determine the correlation between teachers' perceived level of communication skills and teaching performance in developing learners' communicative competence.

\section{Results and Discussion}

\subsection{Teachers' Perceived Level of Communication Skills}

Communication skills in English are composed of macro skills in reading, listening, writing, and speaking (Aclan \& Aziz, 2015). Language competence can only be achieved if one can combine his mastery of the four skills (Renukadivi, 2014).

Reading Skills. Data showed that senior high school teachers' reading skill is superior $(\mathrm{M}=3.45 ; \mathrm{SD}=0.57)$ which means that teachers are critical readers of literary and academic texts.

Reading skill is the information-processing technique that a person automatically applies when prompt with the challenge such as recognizing words and summarizing a story. This skill is unconsciously applied depending on one's purpose which includes practice and following directions (Kadir et al., 2014).

Reading is an important skill both in academic and daily life (Avşar \& Yalçın, 2015). Among teachers, this skill is vital in areas of life such as in academe where reading is required for acquiring knowledge, improving language skills and developing critical and creative thinking skills (Dogan, 2014). Teachers have to read textbooks and other resources for them to be more effective in delivering their lessons (Ajayi, 2016).

Having perceived themselves as superior in reading, teachers must continuously engage themselves with active reading in both literary and academic texts. This means that teachers should devote part of their time for reading to sustain their superior ability in analysis, criticism, synthesis, and identifying secondary meanings in texts (Birch, 2014).

Listening Skills. In terms of listening skills, senior high school teachers rate themselves as superior $(\mathrm{M}=3.41$; $\mathrm{SD}$ $=0.52$ ). This entails that they can effectively receive input while listening in different kinds of situations including formal meetings, radio or television editorials, debates, and even dramatic presentations on stage.

Teachers are always engaged in communication and as they do this, they use their listening skill (Renukadivi, 2014). Teachers listen to students to understand their thoughts (Broström et al., 2014) (Hintz \& Tyson, 2015). Also, 
teachers listen to students and parents air out problems hindering students' academic performance (Bear et al., 2014).

Listening skill is one of the skills a person should have to be successful in his workplace. For teachers, one determinant of successful teaching is the teacher's ability to carefully listen to their learners' communicated ideas and feelings as if they are taking the role of that of a parent at home (Fisher, 2017). In performing such, listening plays a vital part of the process since this skill is considered to be an expression of affection (Floyd, 2014).

Writing Skills. Senior high school teachers perceived themselves as advanced in terms of their writing skills ( $\mathrm{M}=$ $2.95 ; \mathrm{SD}=0.69)$, the skill which they rated themselves the lowest among the skills in communication. This shows that teachers can produce written materials may it be academic or literary. However, they still have to improve themselves in terms of their ability to write output especially formal and publishable articles related to their profession.

Writing is a complex skill and it takes much effort to master it. This skill has underlying foundational skills which include spelling, word choice, and grammar (Graham et al., 2015). Writing, especially in the second or foreign language, is a demanding skill and has long been claimed to be a very difficult skill to acquire (Daud et al., 2016). Mastery of this skill is seen possible when writing is done through gradual and accumulative activities (Munirah, 2017). This explains why SHS teachers' ability to write is somehow not fully developed since they are not required to produce publishable written output.

It is a must for teachers to possess writing skills especially writing academic and publishable articles related to their field. Writing in publication serves as a venue for sharing knowledge and exchange of ideas on innovative practices, something which is encouraged among teachers today (Oermann \& Hays, 2015). Writing, particularly the one that involves composing complex material such as academic or professional text involves training, instruction, practice, experience and purpose (Grabe \& Kaplan, 2014). Therefore, teachers must be given chances and be exposed to avenues for writing journalistic or professional types of text.

Speaking Skills. In terms of their skill in speaking, senior high school teachers affirmed that they are superior in this field $(\mathrm{M}=3.34 ; \mathrm{SD}=0.57)$ which mean that the teachers can perform well both in formal and informal conversations and discussions. As facilitators of learning, speaking skill is the one usually used by teachers every day (Szymanowskl, 2014). Teachers use their speaking skill when sharing information, views, and even feelings (Solar, 2014).

Speaking skill is an important skill to develop (Leong \& Ahmadi, 2017). This skill which is also referred to as oral language production is the ability to use pronunciation signal system, tone and intonation, grammatical and vocabulary structure in English in a communicative situation (Hutabarat, 2015).

The demand for mastery in speaking the English language has become inevitable given knowing that English is now dubbed as the international language. In such case, teachers, who are the trainers of learners should continuously make themselves superior in the field of speaking to serve as models for their students (Lucena \& San Jose, 2016). To ensure that teachers maintain this level in speaking, they must always ask themselves first what they are going to teach and how they are going to do it. This way, they can orchestrate in advance what they are going to say (Romero, 2014).

The overall result of this study reveals that senior high school teachers perceived themselves as superior in terms of their skills in communicating the English language $(\mathrm{M}=3.29$; $\mathrm{SD}=0.59)$.

Table 3. Teachers' Perceived Level of Communication Skills

\begin{tabular}{lll}
\hline \multicolumn{1}{c}{ Constructs } & & SD \\
\hline Reading & 3.45 & 0.57 \\
Listening & 3.41 & 0.52 \\
Writing & 2.95 & 0.69 \\
Speaking & 3.34 & 0.57 \\
Overall & $\mathbf{3 . 2 9}$ & $\mathbf{0 . 5 9}$ \\
\hline
\end{tabular}

Note: Scale: 3.25 - 4.0 - Superior; 2.50 - $\overline{3.24-\text { Advanced; } 1.75-2.49}$ - Intermediate; and $1.0-1.74$ - Novice 


\subsection{Teachers' Perceived Teaching Performance}

The result showed that Senior High School teachers have outstanding teaching performance in terms of developing learners' communicative competence in the English language $(\mathrm{M}=3.29$; $\mathrm{SD}=0.54)$ as perceived by the school heads and the learners. Specifically, they received outstanding rating as proficient communicator $(\mathrm{M}=3.35 ; \mathrm{SD}=$ $0.51)$ and very satisfactory as initiator of communication situations $(\mathrm{M}=3.22 ; \mathrm{SD}=0.57)$.

The teaching performance of Senior High Schools in terms of developing learners' communicative competence was measured in two ways. First was in terms of the teachers' ability to initiate communicative situations that would allow the learners to communicate in English. Second was through the teachers' ability to be an independent participant of communicative situations assuming the role of being the more proficient communicator than the learners.

This result implies that as communicators in English, SHS teachers are observed to be very proficient in communicating using the English language. Teachers are seen to be performing very well in explaining things using the English language, and as they do so, they always observe the correct pronunciation of words and the proper tone of their voices. Also, they can identify students' grammatical errors and can correct them.

As initiator of communicative situations, senior high school teachers sometimes engage their learners in communicative situations. Teachers do so by asking questions for learners to answer, initiating "small talks" with the learners while class activities are going on, and providing learners paired or group activities that would encourage them to speak the English language with the teachers and their fellow learners.

High level of communication skills is prerequisite for employment (Mishra, 2014) especially among teachers (Altan et al., 2014). This can be attributed to the outstanding level of performance in communication and being proficient communicators of SHS teachers. Another cited reason is the fact that part of a teacher's daily job involves communicating making teachers develop their communication skills even more. Teachers use the English language in communicating their lessons, directions, worksheets, and discussions (Aldapa, 2016).

One cited reason for teachers rated very satisfactory as initiators of communication situations is that at times teachers talk too much in class taking away from learners the opportunity to practice their communication skills (Humaera, 2015). At times, teachers articulate students' ideas for them, diminishing students' opportunities to think and communicate for themselves (Wassermann, 2015).

Given the data gathered, teachers should be reminded of the importance of giving learners the opportunity in class to communicate in the English language. They should also be taught on the techniques on how to initiate communicative situations. This can be done during teachers' learning action cell (LAC) and in-service training or during school heads' conference with the teachers.

Table 4. Teachers' Perceived Teaching Performance

\begin{tabular}{lllllll}
\hline \multirow{2}{*}{ Constructs } & \multicolumn{2}{c}{ School Heads } & \multicolumn{2}{c}{ Learners } & \multicolumn{2}{c}{ Overall Rating } \\
& $\mathrm{M}$ & $\mathrm{SD}$ & $\mathrm{M}$ & $\mathrm{SD}$ & $\mathrm{M}$ & $\mathrm{SD}$ \\
\hline Proficient Communicator & 3.34 & 0.55 & 3.35 & 0.47 & 3.35 & 0.51 \\
Initiator of Communicative situations & 3.25 & 0.61 & 3.19 & 0.52 & 3.22 & 0.57 \\
Overall Performance & 3.30 & 0.58 & 3.27 & 0.50 & 3.29 & 0.54 \\
\hline
\end{tabular}

Note: Scale: $3.25-4.0$ (Outstanding); 2.50-3.24(Very Satisfactory); 1.75-2.49 (Satisfactory) 1.0-1.74 (Fair)

\subsection{Correlation between Teachers' Perceived Level of Communication Skills and Teaching Performance}

Results showed that there is no significant relationship between teachers' communication skills and teaching performance in developing learners' communicative competence in English. This is true in all constructs under these two variables. This implies that teachers' skills in reading, listening, writing, and speaking are not related to teachers' performance in class in terms of developing the students' communicative competence (Table 5).

A person's level of communication skill is just an element of a wider aspect of communication which is happening between the teachers and the students. In a classroom setting, teachers' role is not confined within the boundaries of receiving input through reading and listening to later produce something in the form of a written and spoken piece. Rather, teachers are expected to engage themselves to a much more complex form of communication where psychological, social and cultural rules that discipline the use of speech in social settings apply. This kind of communication not only includes linguistic forms of language but also social rules (Lasala, 2014). 
Results of this study confirm that a high level of skills in reading, listening, writing, and speaking does not have a direct correlation to teachers' teaching performance. For these skills to be valuable, teachers should bring and use these in actual interactive communication so that these skills become part of teachers' communicative competence. These ideas support the principle in communicative approach which claims that effective teaching of the English language can happen when the teaching-learning processes are handled by teachers who are more proficient than the learners and by teachers who can initiate communicative situations for the learners.

Table 5. Test of Significant Relationship between Teachers' Perceived Level of Communication Skills and Teaching Performance

\begin{tabular}{lccc}
\hline \multicolumn{1}{c}{ Variables } & r-value & p-value & Remarks \\
\hline Reading and & & & \\
$\quad$ Proficient Communicator & 0.10 & 0.07 & Not Significant \\
$\quad$ Initiator of Communicative Situations & 0.06 & 0.25 & Not Significant \\
$\quad$ Listening and & & & \\
$\quad$ Proficient Communicator & 0.04 & 0.48 & Not Significant \\
$\quad$ Initiator of Communicative Situations & 0.03 & 0.63 & Not Significant \\
$\quad$ Writing and & & & \\
$\quad$ Proficient Communicator & 0.04 & 0.47 & Not Significant \\
$\quad$ Initiator of Communicative Situations & 0.05 & 0.38 & Not Significant \\
$\quad$ Speaking and & & & \\
$\quad$ Proficient Communicator & 0.07 & 0.18 & Not Significant \\
$\quad$ Initiator of Communicative Situations & 0.04 & 0.49 & Not Significant \\
\hline
\end{tabular}

Note: ** means $p \leq 0.01-$ Highly Significant; * means $p \leq 0.05-$ Significant

\section{Conclusion And Recommendations}

This study provides information on the perceived level of senior high school teachers' communication skills in the English language, teachers' teaching performance in developing learners' communicative competence, and the correlation between the two variables. Results of this research show that teachers perceived themselves to be superior in English communication skills while school heads and learners perceived the teachers as outstanding in their performance in developing learners' communicative competence in class. Also, this research proves that the teachers' communication skills in English as to reading, listening, writing, and speaking have no relation to their teaching performance. It is concluded that teachers' communication skills have no significant relationship with teachers' teaching performance in developing learners' communicative competence.

Considering the important findings of this study, it is recommended that school heads provide teachers activities that would sustain their high level of communication skills and outstanding performance in teaching. It is also recommended that input and workshops on these areas be given during school head-teachers' conference and school's learning action cell (LAC) sessions and in-service training. For future studies, it is suggested that research exploring similar objectives be conducted with the variables being measured using appropriate tools and not only through perception.

\section{References}

Aclan, E. M., \& Aziz, N. H. A. (2015). Exploring parliamentary debate as a pedagogical tool to develop English communication skills in EFL/ESL classrooms. International Journal of Applied Linguistics and English Literature, 4(2), 1-16. https://doi.org/10.7575/aiac.ijalel.v.4n.2p.1.

Ajayi, L. (2016). High school teachers' perspectives on the English language arts common core state standards: An exploratory study. Educational Research for Policy and practice, 15(1), 1-25. https://doi.org/10.1007/s10671-015-9174-3

Aldapa, M. L. (2016). Opening the Gates of a GATE Program: A Mixed Methods Study of Recruitment Processes and Retention Practices in One Multicultural Middle School(Doctoral dissertation, Loyola Marymount $\begin{array}{llllll}\text { University). } & \text { Retrieved } & \text { on } & \text { July } & & \end{array}$ 
https://search.proquest.com/openview/9f83ccafa85c8a6a388dcdc50af8351d

Altan, M. Z., McMurtry, D., \& McMurtry, S. (2014). Effective teachers as effective entrepreneurs: results of a tri-nation professional development project. International Journal of Social Entrepreneurship and Innovation, 3(3), 230-244. Retrieved on August 2, 2018 from https://www.inderscienceonline.com/doi/abs/10.1504/IJSEI.2014.067121

Anjum, U. (2017). Needs of Modern Education in Madaaris: Case study in Pakistan. Retrieved on July 18, 2018 from http://iipccl.org/wp-content/uploads/2017/11/239-253.pdf

Avşar, A. Ş., \& Yalçın, S. (2015). Determining the Parental Variables That Explain Students' Reading Success by Using CHAID Analysis. Education \& Science/Egitim ve Bilim, 40(179). https://doi.org/10.15390/EB.2015.2890

Badawood, O. (2015). The features of effective English teachers as viewed by English language teachers and high school students in Saudi Arabia. International Journal of English Language and Linguistics Research, 3(6), 26-34. Retrieved on August 22, 2018 from http://www.eajournals.org/wp-content/uploads

Baliya, R., Teacher, K. V. N., \& Jammu, G. N. (2013). Enhancing writing abilities of primary class students through cooperative learning strategies: An experimental study. International Journal of Behavioral Social and Movement Sciences, 2(1), 294-305. Retrieved on August 22, 2018 from http://ijobsms.in/vol02\%20issue01\%202013\%20p34.pdf

Bear, G. G., Yang, C., Pell, M., \& Gaskins, C. (2014). Validation of a brief measure of teachers' perceptions of school climate: Relations to student achievement and suspensions. Learning Environments Research, 17(3), 339-354. Retrieved on August 16, 2018 from https://link.springer.com/article/10.1007/s10984-014-9162

Birch, B. M. (2014). English L2 reading: Getting to the bottom. Routledge. https://doi.org/10.4324/9781410614933

Broström, S., Johansson, I., Sandberg, A., \& Frøkjær, T. (2014). Preschool teachers' view on learning in preschool in Sweden and Denmark. European Early Childhood Education Research Journal, 22(5), 590-603. Retrieved on August 22, 2018 from http://cds.cern.ch/record/1953563

Camello, N. C. (2014). Factors Affecting the Engineering Students' Performance in the OBE Assessment Examination in Mathematics. International Journal of Academic Research in Progressive Education and Development, 3(2), 87-103. https://doi.org/10.6007/IJARPED/v3-i2/913

Daud, N. S. M., Daud, N. M., \& Kassim, N. L. A. (2016). Second language writing anxiety: Cause or effect? Malaysian Journal of ELT Research, 1(1), 19. Retrieved on July 26, 2018 from http://www.melta.org.my/journals/index.php/majer/article/view/189

Doğan, B. (2014). Prospective Teachers' Reasons: The Importance of Reading a Book. Information World/Bilgi Dunyasi, 15(1). https://doi.org/10.15612/BD.2014.408

Emeck, N. (2018, Oct 01). Students criticise plan to cut classes. The Northern Territory News Retrieved from https://search.proquest.com/docview/2114711700?accountid=149218

Fisher, L. (2017). Researching learners' and teachers' beliefs about language learning using metaphor. Discourse and Education, 329-339. https://doi.org/10.1007/978-3-319-02243-7_17

Floyd, K. (2014). Empathic listening as an expression of interpersonal affection. International Journal of Listening, 28(1), 1-12. Retrieved on July 26, 2018 from https://www.tandfonline.com/doi/abs/10.1080/10904018.2014.861293

Grabe, W., \& Kaplan, R. B. (2014). Theory and practice of writing: An applied linguistic perspective. Routledge. https://doi.org/10.4324/9781315835853

Graham, S., Harris, K. R., \& Santangelo, T. (2015). based writing practices and the common core: Meta-analysis and meta-synthesis. The Elementary School Journal, 115(4), 498-522. Retrieved on August 12, 2018 from https://www.journals.uchicago.edu/doi/abs/10.1086/681964

Graham, S., Santos, D., \& Francis-Brophy, E. (2014). Teacher beliefs about listening in a foreign language. Teaching and Teacher Education, 40, 44-60. https://doi.org/10.1016/j.tate.2014.01.007

Hintz, A., \& Tyson, K. (2015). Complex listening: Supporting students to listen as mathematical sense-makers. Mathematical Thinking and Learning, 17(4), 296-326. https://doi.org/10.1080/10986065.2015.1084850

Hughes, R., \& Reed, B. S. (2016). Teaching and researching speaking. Routledge. 
https://doi.org/10.4324/9781315692395

Humaera, I. (2015). Inhibition in Speaking Performance. Langkawi: Journal of The Association for Arabic and English, 1(1), 31-50. Retrieved on August 22, 2018 from https://www.ingentaconnect.com/content/doaj/24602280/2015/00000001/00000001/art00003

Hutabarat, M. D. (2015). Speech Acts on Company's Presentation in German for Business and Economics. Indonesian Journal of Applied Linguistics, 5(1), 77-85. https://doi.org/10.17509/ijal.v5i1.834

Kadir, N. A., Subki, R. N. S., Jamal, F. H. A., \& Ismail, J. (2014). The importance of teaching critical reading skills in a Malaysian reading classroom. In The 2014 WEI International Academic Conference Proceedings (pp. 208-219). Retrieved on August 2, 2018 from http://www.westeastinstitute.com/wp-content/uploads/2014/06/Norbaiyah-Abd-Kadir-Full-Paper.pdf

Kimonen, E. (2015). Education and society in comparative context. Springer. https://doi.org/10.1007/978-94-6300-373-5

Krebt, D. M. (2017). The effectiveness of role play techniques in teaching speaking for EFL college students. Journal of Language Teaching and Research, 8(5), 863-870. https://doi.org/10.17507/jltr.0805.04

Lasala, C. B. (2014). Communicative competence of secondary senior students: Language instructional pocket. Procedia-Social and Behavioral Sciences, 134, 226-237. https://doi.org/10.1016/j.sbspro.2014.04.243

Leong, L. M., \& Ahmadi, S. M. (2017). An analysis of factors influencing learners' English speaking skill. International Journal of Research in English Education, 2(1), 34-41. https://doi.org/10.18869/acadpub.ijree.2.1.34

Lucena, R. J., \& San Jose, A. E. (2016). Co-operative learning in enhancing the speaking skills of students: A Phenomenological approach. International Journal of Advanced Multidisciplinary Research, 3(2), 67-71. Retrieved on August 2, 2018 from https://www.researchgate.net/profile

Maduegbunam, T., \& Okafor, N (2014). Functional education: an essential tool for bridging the gap in education in nigeria. Retrieved on July 26, 2018 from https://scholar.google.com.ph/scholar

Majidi, A. (2013). English as a Global Language; Threat or Opportunity for Minority Languages? Mediterranean journal of social sciences, 4(11), 33. https://doi.org/10.5901/mjss.2013.v4n11p33

Mishra, K. (2014). Employability skills that recruiters demand. IUP Journal of Soft Skills, 8(3), 50. Retrieved on July 28, 2018 from https://search.proquest.com/docview/1627986150?pq-origsite=gscholar

Mishra, S. (2016). Endogenous Growth Theory and Role of Education. Splint International Journal of Professionals, 3(10), 74. Retrieved from https://search.proquest.com/docview/1906048588?pq-origsite= gscholar

Munirah. (2017). The effectiveness of concept sentence model toward writing skill of persuasive paragraph. Theory and Practice in Language Studies, 7(2), 112-121. https://doi.org/10.17507/tpls.0702.04

Naji Meidani, E., \& Pishghadam, R. (2013). Analysis of English language textbooks in the light of English as an International Language (EIL): A comparative study. International Journal of Research Studies in Language Learning, 2(2), 83-96. https://doi.org/10.5861/ijrsll.2012.163

Nghia, T. L. H. (2015). Vietnamese students' perception of English teacher qualities: Implications for teacher professional development. International Journal of Academic Research in Education and Review, 3(1), 7-19. $\begin{array}{lllll}\text { Retrieved on } & \text { August } & 12, & \text { from }\end{array}$ http://citeseerx.ist.psu.edu/viewdoc/download?doi=10.1.1.675.636\&rep=rep1\&type=pdf

Oermann, M. H., \& Hays, J. C. (2015). Writing for publication in nursing. Springer Publishing Company. https://doi.org/10.1891/9780826119926

Papp, I. C., \& Hajós, L. (2014). Education and working life in Hungary. Acta Technica Corviniensis-Bulletin of Engineering, 7(2), 105. Retrieved on July 26, 2018 from http://acta.fih.upt.ro/pdf/2014-2/ACTA-2014-2-16.pdf

Pearson, S. (2014). The process secondary administrators use to implement twenty-first century learning skills in secondary schools. University of Southern California. Retrieved on July 23, 2018 from https://search.proquest.com/openview

Renukadevi, D. (2014). The role of listening in language acquisition; the challenges \& strategies in teaching listening. International journal of education and information studies, 4(1), 59-63. Retrieved on July 26, 
2018 from https://www.ripublication.com/ijeisv1n1/ijeisv4n1_13.pdf

Rindal, U. (2014). What is English? Acta Didactica Norge, 8(2), Art-14. https://doi.org/10.5617/adno.1137

Romero, B. N. (2013). Descriptive Analysis of Vaughan Systems, Assets and Pitfalls of an Audiolingual Method. Porta Linguarum: revista internacional de didáctica de las lenguas extranjeras, (19), 113-128. Retrieved on August 18, 2018 from https://dialnet.unirioja.es/servlet/articulo?codigo=4593482

Selvi, A. F., \& Yazan, B. (2013). Teaching English as an International Language. TESOL International Association. 1925 Ballenger Avenue Suite 550, Alexandria, VA 22314. Retrieved on August 22, 2018 from https://eric.ed.gov/?id=ED549560

Smith, L. E. (2015). English as an international language: No room for linguistic chauvinism. Journal of English as a Lingua Franca, 4(1), 165. https://doi.org/10.1515/jelf-2015-0002

Solar, E. (2011). Prove them wrong be there for secondary students with an emotional or behavioral disability. Teaching exceptional children, 44(1), 40-45. https://doi.org/10.1177/004005991104400105

Stejskal, L., \& Stávková, J. (2014). Education as an income situation determinant of a consumer. Acta Universitatis Agriculturae et Silviculturae Mendelianae Brunensis, 58(6), 483-490. https://doi.org/10.11118/actaun201058060483

Szymanowskl, A. R. (2014). Voice disorders in teachers: Examining the problem and evaluating prevention. Journal of Singing-The Official Journal of the National Association of Teachers of Singing, 71(2), 201-206. Retrieved on August 26, 2018 from https://search.proquest.com/openview/6f9e1c9bc4146ca754c15fd7da65f5ca/1.pdf?pq-origsite=gscholar\&cb $1=971$

Tyagi, B. (2013). Listening: An important skill and its various aspects. The Criterion An International Journal in English, 12, 1-8. Retrieved on July 23, 2018 from https://s3.amazonaws.com/academia.edu.documents/35052141

U.S. students need 21st century skills to compete in a global economy, voters say. (2017, Oct 10). U.S.Newswire. Retrieved from https://search.proquest.com/docview/451013378? accountid=149218.

Wassermann, S. (2015). Making meaning from scientific investigations and living with the uncertainties of $\begin{array}{llll}\text { teaching science as inquiry. Childhood } & \text { Education, 91(6), }\end{array}$ https://doi.org/10.1080/00094056.2015.1114795

\section{Copyrights}

Copyright for this article is retained by the author(s), with first publication rights granted to the journal.

This is an open-access article distributed under the terms and conditions of the Creative Commons Attribution license (http://creativecommons.org/licenses/by/4.0/). 